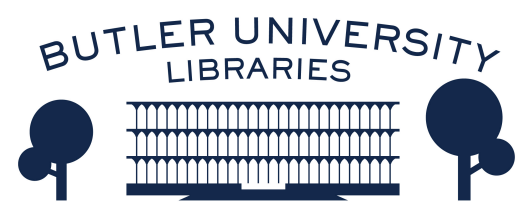

Journal of Hindu-Christian Studies

\title{
Yoga and the Jesus Prayer-A Comparison between aștānga yoga in the Yoga Sūtras of Patañjali and the Psycho-Physical Method of Hesychasm
}

\author{
Eiji Hisamatsu \\ Ryukoku University \\ Ramesh Pattni \\ Oxford University
}

Follow this and additional works at: https://digitalcommons.butler.edu/jhcs

\section{Recommended Citation}

Hisamatsu, Eiji and Pattni, Ramesh (2015) "Yoga and the Jesus Prayer-A Comparison between aștānga yoga in the Yoga Sūtras of Patañjali and the Psycho-Physical Method of Hesychasm," Journal of HinduChristian Studies: Vol. 28, Article 7.

Available at: https://doi.org/10.7825/2164-6279.1606

The Journal of Hindu-Christian Studies is a publication of the Society for Hindu-Christian Studies. The digital version is made available by Digital Commons @ Butler University. For questions about the Journal or the Society, please contact cbauman@butler.edu. For more information about Digital Commons @ Butler University, please contact digitalscholarship@butler.edu. 
Hisamatsu and Pattni: Yoga and the Jesus Prayer-A Comparison between a?t?nga yoga in th

\title{
Yoga and the Jesus Prayer-A Comparison between aștānga yoga in the Yoga Sütras of Patañjali and the Psycho-Physical Method of Hesychasm
}

\author{
Eiji Hisamatsu \\ Ryukoku University \\ and \\ Ramesh Pattni \\ Oxford University
}

\section{INTRODUCTION}

The present article will try to show differences and similarities in description about the ascetic teaching and mystical experience of two totally different spiritual traditions, i.e. in regard to the "Jesus Prayer" in the late Byzantine era and "yoga" in ancient India. A prayer made much use of by Christians in the Eastern Orthodox Church is the so-called "Jesus Prayer" or "Prayer of the heart," including a short phrase,

Eiji Hisamatsu earned a doctorate in theology at the University of Vienna. He is a professor of comparative religious thought at Ryukoku University in Japan. He is also Dean of the faculty of International Studies. His major area of academic expertise is Eastern Christian spirituality, and his other area of academic interest is interreligious dialogue. His publications include Gregorios Sinaites als Lehrer des Gebetes (Münsteraner Theologische Abhandlungen Bd. 34), Altenberge: Oros Verlag, 1994; The Psychophysical Method of Prayer: Byzantine Hesychasm of the 14th Century, 2009, Kyoto University Press (in Jap.); Rudolf Otto, Das Heilige, trans. by Eiji Hisamatsu. Tokyo: Iwanami Shoten, 2010 (in Japanese, 465 pp.); Eastern Orthodox Church: Wisdom of the East. Tokyo: Kodansha, 2012 (in Japanese, 272 pp.) His present and future academic projects include interreligious dialog between Christianity and mainly Asian religions, in the area of mysticism.

Ramesh Pattni's dissertation, "'A Psychological Understanding of the Yogasūtra of Patañjali with a Comparative Phenomenology of Samādhi and Flow," was completed in 2015 at the University of Oxford. His other area of specialization is in Advaita Vedānta. He presently teaches at the Oxford Centre for Hindu Studies. He also teaches Sanskrit and Advaita Vedānta at the Chinmaya Mission. In addition, he is a participant in numerous interfaith organizations in the UK. Among these he is currently the Chair of the Interfaith Committee of the Hindu Forum of Britain and also the Co-Chair of the Hindu-Christian Forum, a national organization which is supported by the Archbishop of Canterbury.

Journal of Hindu-Christian Studies 28 (2015):55-75 
"Lord Jesus Christ, Son of God, have mercy on me" that is repeatedly and continuously recited. ${ }^{1}$ The Jesus Prayer began to spread generally in the Eastern Church with the birth of "hesychasm," a spiritual movement of Orthodox monasticism in the 14th century Byzantine empire. But a significant part of this movement was not so much the establishment of the Jesus Prayer itself but a special psychophysical technique which began to be practiced with this prayer by monks on the Holy Mountain of Athos. What interests us in this regard is that this psycho-physical method, including a special bodily posture and a breath control technique, appears to be quite similar to the methods set out in another religious tradition, namely that of yoga that developed from ancient times in India. Because of its impressive similarity, a Byzantinologist, Endre von Ivánka, called the practitioners of hesychasm "byzantinische Yogis." ${ }^{2}$ For this present article we take up the Yoga Sütras of Patañjali with its comprehensive method of yoga, and clarify similarities and differences in the conceptual and methodological frameworks of the two systems.

\section{The Yoga Sütras of Patañjali}

Some basic notions of yoga had been already set out in the Śvetāśvatara Upanișad, which was composed around the $3^{\text {rd }}$ century $\mathrm{BCE}$, but some terms of yoga like "āsana" (bodily postures) and "prāṇāyāma," or breathing practices, did not appear in this ancient Hindu text. These are, however, incorporated in the Yoga Sütras in which there is a systematic compilation of the techniques of yoga. Composed between $100 \mathrm{BCE}$ and $500 \mathrm{CE}$ by Patañjali, the Yoga Sütras contain instructions to bring the mind to cessation of its vrrttis or mental modifications. Patañjali brought together many ideas and techniques developed over many centuries and codified them into the Yoga Sūtras. There are 195 sūtras in the text distributed over four chapters: Samādhi Pāda, Sādhanā Pāda, Vibhūti Pāda and Kaivalya Pāda. ${ }^{3}$ The text not only describes the mental phenomena which need to be controlled but also the various states of the mind, the different types of practices, and the various factors that influence the activities of the mind.

In sūtra I.2 Patañjali gives a definition of yoga itself: "Yoga is the cessation of the modifications of the mind." ${ }^{4}$ And it is only when this functioning of ordinary awareness is ceased that the "Seer" becomes established in its true nature (YS I.3). These two sūtras summarise the means and end of yoga, the end described as being established in the state of "kaivalya" or aloneness of the primordial consciousness "Purusa" (or Seer) which becomes untangled from the evolutes of matter (Prakrti) through the methods of yoga aimed at ceasing the modification of the mind.

The modifications of the mind (citta vrttti) are categorised into five by Patañjali (YS I.6 ${ }^{5}$ ) and consist of:

1) pramāna or "right cognition" arrived at through the means of pratyakșa (perception), anumāna (inference) and agama (reliable testimony). This is the focus of epistemology the means of valid knowledge and the sources from which we can derive this knowledge.

2) viparyaya or "error," misconception, perceiving something to be other than it really is (atadrupa). Vyāsa says that with the right cognition "there is really just one moon that sublates the misconception of the double-moon experience" ${ }^{6}$. 
3) vikalpa or "conceptual construction" is an intellectual process which leads to the formation of concepts, judgements, views, and opinions, i.e. conceptualisation. The vrrttis or modifications, which fall within this category, are related to abstraction of ideas whether in forming concepts or imagination of objects in the mind.

4) nidrā or "sleep," defined by Patañjali as the absence of experience in the mind. Nidrā does not refer to the dream state of the mind in which there is content or experience of some kind.

5) smrti or "memory" is the recollecting or retaining of previously experienced impressions. Patañjali speaks of smrtti as the non-deprivation of the impression of the object or experience.

Whicher considers that the five categories of the modifications "consist of the normal range of human functioning, encompassing the three modes of everyday transactions, including things (as registered in pramāna), mental content or objects whether remembered (smṛti), conceptualised (vikalpa), or erroneous (viparyaya), and sleep (nidrā)"7. Yoga is the restriction of all types of vrttis that then leads the practitioner towards the attainment of the goal of kaivalya or aloneness of the Puruṣa.

The Yoga Sütras contain another concept, kleśa, translated as "cause of affliction" or "seed of suffering." The kleśa principle in Patañjali's text is described by Feuerstein as that which is said to "circumscribe the fact that every organism, on attaining selfconsciousness, finds itself in the existential situation where it has become aware of its own self-awareness but has become confused as to the true nature of this awareness, and the organism is, as it were, compelled to act out of a false identity." 8 This false identity resulting from asmitā, the affliction of individuation, leads to the ongoing misidentifications of the Purusa or Seer and the modifications of the mind. The primary affliction of avidyā or ignorance is the root of the other four kleśas. The attachment (rāga) and aversion (dveșa), the 'emotive core' of the kleśas, signify the affective dimension of the vrttis. ${ }^{9}$ Aversion or dvesa is produced with a recollection of painful experiences, as a result of such past impressions. In general, there is a movement towards attainment of sukha (pleasure) and away from duhkha (suffering/pain). Avidyā or nescience, according to Vyāsa, is the latent, subliminal tendency (vāsana) of erroneous thinking. ${ }^{10}$ This foundational kleśa is described as the kśetra (field), and the prasava-bhūmi or breeding ground, for four other causes of afflictions. Yoga provides a method by which these kleśas become attenuated, resulting in greater control and mastery of the mind.

\subsection{Outline of aștānga-yoga}

The discipline and control of the mind is brought about by the systematic practice of the eight limbs of yoga. Thus Patañjali's yoga is sometimes also referred to as aștāninga yoga (așța, meaning eight and anga - limbs). These are as follows:

\section{1.a. yama and niyama: the restraints and observances}

The restraints (yama) and the observances (niyama) constitute an ethical code that is indispensable as a condition for the practice of yoga. Their purpose is to order the external relations of the yogin so that on the one hand, it takes him towards 'punya' or merits derived 
through ethical behavior, and on the other, takes him away from actions based on personal desires that arise from selfishness.

1) yama consist of five 'restraints' which are the ethical dimension of yoga: ahimsā (nonviolence), satya (truthfulfulness), asteya (nontheft), brahamcārya (celibacy) and aparigraha (non-avarice). ${ }^{11}$

2) niyama are the five disciplines consisting of: śauca (purification), santoṣa (contentment), tapas (austerities), svādhyāya (study/recitation) and îsvara praṇidhāna (surrender to God). ${ }^{12}$

\section{1.b. āsana: the postures}

3) Âsana (posture) of the body is characterised by motionlessness and pleasantness (sthira sukham āsanam) ${ }^{13}$ and results in relaxation of the body, meditation on the Infinite. It also gives immunity from the 'dualities' like heat and cold (prayatna śaithilya ananta samāpattibhyām). ${ }^{14}$ In other words, the practice of posture has effects which go beyond just relaxation of the body. They develop the capacity of the mind to forebear the dualities and help the practitioner of yoga to attain onepointedness of the mind, as it is not distracted by such dualities.

\section{1.c. prānāāāma: the control of breath}

4) Prānāyāma (breath control): The āsana (posture) being achieved, prānāyāma is the practice of controlling the exhalation and inhalation of breath together with the stoppage of breath altogether. Thus prānāyāma has three forms: inhalation, exhalation, and suspension of breath. When this is practiced according to the place, time and the number of breaths, it gives rise to sūkșma (subtle) and dīrgha (long) breaths, and finally brings about the "fourth (level of breath control)" (bāhya ābhyantara) which "pertains to going beyond external and internal operations." The result of this is that "the covering over the light (of knowledge) is destroyed" and "the mind is then ready to practice meditative concentration (dhāraṇā)."15

\section{1.d. pratyāhāra, dhāraṇā, dhyāna, samādhi}

5) Pratyāhāra (withdrawal of the senseorgans from their objects). The mind which is subject to the activities of the senses is constantly pulled towards their objects, and this technique of pratyāhāra results in an inward turning of attention and thus away from the sense objects. This occurs, according to Patañjali, when the senses 'disconnect' from their objects, and here the mind is said to follow its own nature. Vyāsa, the commentator of the Yoga Sütras, illustrates this with the example of the king of bees which, when it flies, is followed by the other bees, but as it settles down, so do all the other bees. This implies that when the mind is under control through fixing attention on its inner object, the senses also 'settle' down. From the practice of pratyāhāra is said to come the mastery of the mind. The first five limbs of the aștānga yoga take the practitioner to the inner world, starting from the external yama to pratyāhāra, which is the turning point of the mind towards an inner focus. The three remaining limbs of yoga are called the "inner practices," as they relate to the mind only.

6) Dhāraṇa (concentration), says Patañjali, involves the fixing of the mind in "a specific place" (deśa bandha). ${ }^{16}$ Although there is no mention by Patañjali about what object to focus on, the commentators have recommended different parts of the body to fix the attention on, including the circle of the navel, the lotus of 
the heart or the tip of the tongue or "to any external object" (bāhye vā vișaye'). The object can also be an internal image of God, the attractiveness of which at once fixes the mind.

7) Dhyāna (reflective meditation) is when the mind has fixed its attention on an image or idea, and there is an unbroken flow of thought towards this inner object, to the exclusion of non-related thoughts. Here we see that the practice of dhyāna is dependent on the previous limb. If the mind is not able to fix its attention on an object, it cannot contemplate on it without interruption, as it will be distracted. In other words, these two limbs together with the last limb of samādhi are stages leading to progressive attainment of greater states of absorption.

8) Samādhi (meditative absorption) is the final limb of aștānnga yoga and the third element of the collective stages of dhāranāa dhyāna and samādhi. Together these three are referred to as samyama, the practice of which on various objects and ideas leads to the development of various powers or siddhis. Vyāsa comments on samādhi, saying that it is achieved when the mind becomes so absorbed in the object that it loses all sense of self consciousness. In this state the mind is said to become like a clear crystal, only reflecting the surface on which it is placed. In this final stage of yoga, the object alone remains in consciousness. There is no longer a distinction between the subject and the object, and what remains is the Consciousness or Puruṣa by itself.

\subsection{Prakrti and Puruṣa}

Sāmkhya is considered to be one of the oldest Hindu traditions and is sometimes conceived as an atheistic philosophy, characterised by its dualist model of Puruṣa (consciousness principle) and Prakrti (matter principle). According to the classical text of Sāṃkhya, the Sāṃkhya Kārikā written by Iśvarakṛṣna, the principles of Puruṣa and Prakrti consist of the twenty-five components, tattva, that constitute the entire metaphysical, phenomenal, psychological, ethical and physical world in terms of their embodiment and experience as individuals. With the conjunction of the two primordial unmanifest principles, there arises both the phenomenal world and the world of the individual. Falsely identifying with the individual material components of Prakrti, the individual believes oneself to be the doer of the actions and the enjoyer of the experiences (bhoga). The claim of the Sāmkhya philosophy is that ultimate relief from suffering of repeated rebirths can only be achieved through the process of discrimination (viveka), i.e. discerning the separate ontology of Puruṣa and Prakrti. Sāmkhya stresses the importance of knowledge for liberation. These are the principles and precepts that are taken up by Yoga and framed into a system of practice that brings about the state of kaivalya or the aloneness of the Purușa.

\section{3. kaivalya: "liberation" or "aloneness"}

The term Purușa is a key one in the metaphysics of the dualistic sāmphya philosophy, which represents one of the saddarśana or six perspectives of reality in Hinduism. Although the term Puruṣa was used in the Vedic texts in a slightly different way, in Sāmkhya it signifies the primordial consciousness principle or 'root' consciousness. Prakrti is the material principle of Sāmkhya dualism and is a wider idea of matter and consists of various categories that appear as 
evolutes of this unmanifest principle. It also includes the categories of the intellect (buddhi), the individuality (ahamkāara) the mind (manas) and the tattva, all of which comprise the "world of experience." ${ }^{17}$ The evolutes of the matter principle are governed by the three qualities or guna, consisting of sattva (light), rajas (passion) and tamas (inertia or darkness). The Purusa is described as having properties such as absoluteness, permanent immutability and eternity. The individual comes into existence when the Purușa comes into conjunction with the Prakrti, creating the world of experience. This conjunction has no effect on the Purusa, itself remaining in its permanent immutability. The phenomenal world, according to Yoga, exists not for itself but for the Purusa. The ultimate goal of Yoga is to disentangle the Purușa and Prakrti whereby the Purușa re-establishes itself in its own nature in the state of kaivalya (aloneness). This state can be attained when the phenomenal world or the evolutes of Prakrti return to the original state by a process which is described as 'turning back' (pratiprasava) ${ }^{18}$ of the evolutes.

To summarise, Patañjali's Yoga adopts this dualistic framework of Sāmkhya and provides the practical methods by which the separation of the Purușa and Prakrti can be attained. At the heart of yoga practice is the control of the mind (citta), reducing its modifications through practice of the eight limbs of yoga and dispassion towards the world. This enables the yogin to reach high states of concentration and self-absorption, with a progressive involution of prakrti and final liberation of the Purușa from the entanglement with Prakrti, resulting in kaivalya.

\section{Jesus Prayer}

\subsection{Outline of hesychasm}

Hesychasm is a term denoting the Eastern Christian tradition of inner, mystical prayer associated primarily with the monks of Mt. Athos. It refers to a type of contemplation with a psycho-physical method of praying with the Jesus Prayer ("Lord Jesus Christ, Son of God, have mercy on me (a sinner)"), which emerged in its most explicit form between the thirteenth and the fourteenth century on Mount Athos. The recitation of the Jesus Prayer involves specific bodily postures and is accompanied by very deliberate breathing patterns. This physical method was regarded simply as a useful accessory to the main purpose, to secure what is termed as "the union of the mind with the heart," so that prayer became "prayer of the heart."

The goal of this method is the "theoria," i.e. a mystical state of contemplation of the Divine Light that is identified with the light revealed at Christ's transfiguration on Mt. Tabor. The practice of the hesychast method of prayer requires one to have the instructions from a spiritual guide. This method is not meant to be used unless one is a person of genuine humility and sanity, and filled with wisdom and peace. Thus it requires preparation of the mental and moral aspects of the person before it can be used.

\subsection{Psycho-physical method}

The earliest detailed descriptions of a physical technique occur in two texts, the first dating from the late thirteenth century, the second in all probability more or less contemporary with it: 
1) On Watchfulness and the Guarding of the Heart (Peri nepsôs kai phylakês kardias) ${ }^{19}$ (abr: Peri nepsôs) written by Nikephoros the Hesychast. ${ }^{20}$ 2) A treatise traditionally attributed to St. Symeon the New Theologian (959-1022), Method of Holy Prayer and Attentiveness (Methodos tês hieras proseychês kai prosochês $)^{21}$ (abr: Methodos), also entitled, On the Three Methods of Prayer.

It is now generally agreed that the New Theologian may not have been the true author of the Methodos. Fr. Irénée Hausherr, in his edition of the Greek text of the Method, suggests that it may have been written by Nikephoros himself, but conclusive proof for this assertion is lacking. Whoever the author may be, the text cannot have been written much after the year 1300, and perhaps belongs to the late thirteenth century.

The physical technique is next mentioned by an influential writer slightly later in date than Nikephoros, St Gregory of Sinai (d. 1346), who lived on Athos during the early years of the fourteenth century. It seems likely that he learnt the technique on the Holy Mountain, although he may have been initiated into it while in Crete, before going to Athos. Gregory nowhere refers to Nikephoros, and makes no direct references to the treatise. In the text On Watchfulness, likewise, he does not explicitly quote the Methodos attributed to Symeon. While he may well have been familiar with these two works, it is possible that he acquired his knowledge of the physical technique from oral tradition rather than from the written texts.

The psycho-physical method of the Jesus Prayer in the above mentioned documents of Nikephoros and Ps.-Symeon is quoted below:
From the Peri nepsôs by Nikephoros:

First of all, make your life calm, remove your worry, and make everything peaceful. Seat yourself, then concentrate your intellect, and lead it into the respiratory passage through which your breath passes into your heart. Put pressure on your intellect and compel it to descend with your inhaled breath into your heart. Once it has entered there, what follows will be neither dismal nor glum. Just as a man, after being far away from home, on his return is overjoyed at being with his wife and children again, so the intellect, once it is united with the soul, is filled with indescribable delight.

Therefore, brother, train your intellect not to leave your heart quickly, for at first it is strongly disinclined to remain constrained and circumscribed in this way. But once it becomes accustomed to remaining there, it can no longer bear to be outside the heart. For the kingdom of heaven is within us (cf. Luke 17:21); and when the intellect concentrates its attention in the heart and through pure prayer searches there for the kingdom of heaven, all external things become abominable and hateful to it. If, then, after your first attempts you enter through your intellect into the abode of the heart in the way that I have explained, give thanks and glory to God, and exult in Him. Continually persevere in this practice and it will teach you what you do not know. Moreover, when your intellect is firmly established in your heart, it must not remain there silent and idle; it should constantly repeat and meditate on the prayer, 'Lord Jesus Christ, Son of God, have mercy on $m e^{\prime}$, and should never stop doing this. For this prayer protects the intellect from distraction, renders it impregnable to diabolic attacks, and every day increases its love and desire for God. ${ }^{22}$

From the Methodos by Ps.- Symeon:

Then sit down in a quiet cell, in a corner by yourself, and do what I tell you. Close the door, and 
withdraw your intellect from everything worthless and transient. Rest your beard on your chest, and focus your gaze, together with the whole of your intellect, upon the centre of your belly or your navel. Restrain the drawing in of breath through your nostrils, so as not to breathe easily, and search inside yourself with your intellect so as to find the place of the heart, where all the powers of the soul reside. To start with, you will find there darkness and as impenetrable density. Later, when you persist and practice this task day and night, you will find, as though miraculously, an unceasing joy. For as soon as the intellect attains the place of the heart it beholds itself entirely luminous and full of discrimination. From then on, from whatever side a distractive thought may appear, before it has come to completion and assumed a form, the intellect immediately drives it away and destroys it with the invocation of Jesus Christ. From this point onwards the intellect begins to be full of rancor against the demons and, arousing its natural anger against its noetic enemies, it pursues them and strikes them down. The rest you will learn for yourself, with God's help, by keeping guard over your intellect and by retaining Jesus in your heart. As the saying goes, sit in your cell and it will teach you everything. ${ }^{23}$

\section{Comparison of the two traditions}

We shall attempt a comparative study of the two methods shown in the heyschast texts and the method of the Yoga Sütras. As for the Jesus Prayer, we shall refer to some texts by Gregory of Sinai and other hesychast literature in subsequent sections. The approach of this comparison is to seek to understand the underlying theological and metaphysical principles on which the practices are based and therefore attempt to explain the similarities and differences in terms of these frameworks. Although we see the similarities at more superficial levels, the greater the depth of our examination the more differentiation is observed in the details of these practices. We of course assume that there are no historical contacts between these two widely different traditions, but the knowledge may have been diffused to the West through Arab travelers and writers such as the scholar Al-Biruni, one of the major figures in medieval Islamic period, who in fact wrote about the Yoga Sutras in the $10^{\text {th }}$ CE.

\subsection{Purification}

Of the yogic eight limbs (aștānga), the first two, restraints (yama) and disciplines or observances (niyama), are preliminary practices of yoga and consist in the cultivation of morality and discipline. The goal of this cultivation is purification of the individual of egoism and selfishness. The restraints aim at the purification from ethical disorder and the observances are ordered to purification from kleśa or causes of afflictions in the mind. In brief, the two initial limbs are for regulation and control of the entire life style and a preparation for the other practices of yoga.

In this respect, we see a common motive in the method of the Jesus Prayer of the hesychast tradition. This can be pointed out in the recommendation of Nikephoros: "First of all make your life calm, remove your worry, and make everything peaceful." He put this recommendation at the very beginning of his instruction. In fact, this is not just casual advice but an idea rooted in the deep monastic tradition of the Eastern Christianity. We have also mentioned above that this practice was not recommended to be commenced unless the person had genuine humility and sanity, and was filled with wisdom and peace. This 
preparation also appears to point towards attenuation of the ego and increase of the practice of the virtues to bring peace and wisdom. In other words, certain preparatory conditions need to be established before the practice can begin. The instructions may be related to developing a moral life and also disciplines that bring about peace and wisdom.

The idea of monastic life of eastern Christianity was established by Euagrios Pontikos (345 - 399), who played an active role in the early monastic movement of the fourth century in Egypt. He divided the way to perfection of monastic life into two aspects: "ascetic practice" (praxis) and "contemplation" (theoria). The praxis is a way of physical and mental ascetic practices for "purification" of the soul from the "passions." The direct purpose of the praxis is namely "apatheia," a state of the soul completely purified. ${ }^{24}$ Only when this apatheia has been attained, the theoria is enabled, because the inevitable condition for contemplation is an absolute silence of the "intellect" (nous) as the highest faculty of soul which is taken as the subject of contemplation. Since what disturbs this perfect stillness of nous is passion, the apatheia is in the strict sense an aggressive resistance that can refuse the intervention of such passion. There is a parallel here in the Yoga Sütras where the idea of "vairāgya" is introduced as a means to achieve the concentration of the mind. Vairāgya means dispassion towards that which is seen and that which is described in the scriptures, or that which is unseen. This is a necessary condition for the yogin, as otherwise the mind will attend to things of the world which take it away from contemplation on the truth of Purusa. What we mentioned above is also similar in principle to the first two limbs of așțānga-yoga. At the starting point of training in yoga, an improvement of the life condition is particularly important. With unrest, hesitation, selfishness or hypocrisy and without a purified mind, it would be difficult to be devoted to the ascetic life. Only if the outer life is purified and becomes peaceful, the inner life becomes calm, and ascetic practices can be carried out without any disturbance.

What, then, is "theoria"? One can say that it is a "mystical experience of light." It can be compared with an ultimate state of yoga called samādhi or kaivalya, which, however, is the direct experience of the self-luminous Purușa. Later we discuss the concrete contents of the theoria, but here we point out that the Jesus Prayer with the psycho-physical method was formulated and performed just for the purpose of this mystical experience. In order to attain this experience of theoria, the hesychasts of the $14^{\text {th }}$ century practiced this method of prayer. However, it must be pointed out that it was a common understanding of the hesychast that the theoria is possible only for those who have accomplished purification through a long process of praxis.

\subsection{Posture of sitting}

The hesychasts are recommended to seat themselves for the Jesus Prayer, a common recommendation by both Nikephoros and Ps.Symeon. The posture of sitting here is slightly unusual: The instructions are to sit not directly on the floor, but on a low chair, or stool, of height of around 20-25 centimeters, which is suggested in the document of Gregorios Sinaites. ${ }^{25}$ The hesychasts took a forward-bent posture, lowering the head slightly forward. Gregorios Sinaites states that the posture 
should be taken up "with bending the body persistently," ${ }^{26}$ and Ps.-Symeon says, "rest your beard on your chest, and focus your gaze, together with the whole of your intellect, upon the centre of your belly or your navel." suggesting a certain synchronization of this kind of bodily posture and concentration.

As can be easily imagined, this posture of sitting is by no means comfortable but rather a severe posture that is unsustainable over a long period of time. Actually, Gregorios explains that this posture induces "an acute pain on chest, shoulder or throat" and "discomfort caused by tightness and pain" which require "patience." ${ }^{27} \mathrm{He}$ directs furthermore that one should "not stand up early because of the sharp pain." ${ }^{28}$ However, no hesychast document makes clear the meaning of the posture of sitting accompanied by such pains and its relationship to theoria. It seems strange, because the pain caused by such an uncomfortable posture should, it seems, produce nothing but a distraction, disturbing the inner silence.

But we surmise that this posture presents a certain instructive meaning rather than a purely technical meaning, if we look at the nature of the Jesus Prayer. The Jesus Prayer originated in an old tradition of the Eastern spiritual concept of so-called "penthos," one of the most important virtues. ${ }^{29}$ Penthos is a clear awareness of oneself as a sinner and thus a deep feeling of grief because of that awareness. The Jesus prayer expresses this feeling of penthos in the phrase "Lord Jesus Christ, Son of God, have mercy on me." We think the physical pain caused by a continuous recitation of the Jesus Prayer within an uncomfortable posture would serve as a physical expression of the penthos grief. We think the hesychasts find it significant to participate physically in the cry of the heart, asking God to forgive their sin which the phrasing of the prayer expresses. In brief, the pain contains a penitential component.

By contrast, yoga has a positive purpose for taking up the body posture. These are intended to train the body and regulate muscles as well as help blood circulation. The Yoga Sütras state that "the posture should be steady and comfortable. It results in a relaxation of effort," and although Patañjali himself does not specify what kind of posture is to be practiced, the commentator Vyāsa lists some of the postures. There are several types of posture, but in general they are divided into two types: One type of posture is easy to keep for a long time such as the "lotus position" (padmāsana) or the "hero pose" (virāsana). On the other hand, the bodily posture aiming at physical training such as 'bow pose' (dhanurāsana) or "peacock pose" (mayūrāsana), may be exercised for a short time or a longer time, depending on the degree of intensity desired. However, based on the description "steady," "comfortable," and "relaxed," it can be presumed that here "lotus position" or some similar posture is intended, suitable for long periods of meditation. In marked contrast, the posture adapted for the Jesus Prayer is intended to cause discomfort and even pain and the forward-bent posture is maintained with patience and forbearance.

\subsection{Regulation of breathing}

Ps.-Symeon mentions: "Restrain the drawing in of breath through your nostrils, so as not to breathe easily." It is apparent here that control of the breath is to be practiced consciously. The context indicates that this restraint of breathing should be done in the 
forward-bent posture and with this breathposture combination one should "search inside oneself with one's intellect so as to find the place of the heart." When one, as Ps.-Symeon asserts, "persists and practices this task day and night, $\cdot$ - the intellect attains the place of the heart (topon tês kardias)." The description Nikephoros gives is even more concrete. He states that one should pay attention to breathing in from the nostrils: "concentrate your intellect, and lead it into the respiratory passage through which your breath passes into your heart. Put pressure on your intellect and compel it to descend with your inhaled breath into your heart." According to Ps.-Symeon, with this practice, the breath "passes into your heart." Nikephoros suggests that the intellect (nous) would move through this "respiratory passage into the heart." The nous is imagined as if it were an independent organism that is led into the heart by the respiratory power.

This introduction of nous into the heart signifies a complete stillness of mind. The nous is the supreme faculty of the human mind and the subject of contemplation, but it is the heart, as the root of holistic life, that rules and controls this faculty. According to BakicHayden "nous does not correspond to the current use of intellect as a discursive rationality grounded in sense perception, but rather it is a spiritual intellect which has a potential for a direct apprehension of the eternal truths about God and the meaning of the created world (gnosis)." ${ }^{30}$ In other words, it is thought that the nous can fulfill its function by having its own proper position in the heart. That is a reason why Ps.-Symeon and Nikephoros call the heart "home," 31 and the nous reaches this home through the right practice. However, according to hesychast thought, the nous can easily "protrude" from the sphere of control of the heart, move about arbitrarily and cause distraction and tumult in the soul. Therefore, it is necessary to set the nous in a quiet state if one is to devote oneself to contemplation and prayer. To attain this, the action of nous must be placed in the heart or the "introduction of nous into the heart."

Turning now to the Yoga Sütras, we are told about breath regulation (prānāyāma) as follows: "When āsana (posture) has been perfected, there arises breath control which involves stopping or control of the process of inhalation and exhalation. It is the operation of exhalation, inhalation and suspension, observed with regard to place, time and number, (and) becomes long and subtle." ${ }^{32}$ Here three aspects of respiratory movement, namely inhalation, exhalation, and cessation of breath are distinctively mentioned, and time is assigned to each of the three steps. The text does not give any further details about this practice, but it is presumed that the yogin would know these variables precisely. As a result, the breathing becomes gradually quieter, slower and more subtle, and the tradition says that the one who is proficient in yoga breathing is able to cease breathing for a considerably long period of time. But the Yoga Sütra text does not make it as clear as the hesychastic literature how the breathing method could be related theoretically to tranquility of mind. It explains, however, that through prānāyāma accompanied by āsana, "the veil covering the light" of the true self vanishes, and the mind develops the capacity for intense concentration (dhāranāa). ${ }^{33}$ Hence the combination of prānāyāma and āsana is a preparatory stage for the dhārañā which is 
parallel to the process of bodily posture and breath control as a preparatory stage for the Jesus Prayer. It should be noted that Eliade cautions against the "external analogies" between the breathing exercises in the two traditions. ${ }^{34}$ The practice of prānāyāma with āsana also gives "freedom from the dualities". ${ }^{35}$ The dualities (dvandva) are the environmental influences on mind and body. Freedom from the dualities therefore signifies that the stillness of mind cannot be disturbed any more by dualities such as heat and cold. Thus breath control or prānāyāma achieves a refined breathing which has the capacity to make the mind available for intense concentration, having attained the freedom from dualities.

\subsection{Concentration of mind on an object}

The Yoga Sūtras explain that through the method of the discipline of the body (āsana) and breath regulation (prānāyāma) the citta or mind is no more agitated by external environmental factors. Because these influences are through the senses, it can be said that the yogin gains mastery over the senses. These senses are called "indriya," and the stage in which they are completely controlled is the fifth limb called "pratyāhāra." ${ }^{36}$ Pratyāhāra is the process of "disassociation" of the senses from their sense objects whereby they no longer affect the mind, and mastery is gained over the senses by this practice. This inward movement of attention through the practice of pratyāhāra makes the mind ready for the next stage, the sixth limb, namely "dhāraṇā" (concentration).

The Yoga Sūtras define dhāranāa as "fixing the mind in a specific place," that is, retaining the attention on an object over a long period of time and excluding everything else. We have already pointed out that the object in this case can be chosen relatively freely in the yoga system. The Yoga Sütras themselves tell us nothing about such chosen objects, but the Bhāṣya or the commentary on the Yoga Sütras by Vyāsa, refers to such objects as navel circle, heart, glabella, and the tip of the tongue as well as any external object. ${ }^{37}$ Here the mention of "navel circle"' (nābhicakre) is remarkable, as this bodily region is mentioned also in the text of Ps.- Symeon: "Rest your beard on your chest, and focus your gaze, together with the whole of your intellect, upon the centre of your belly or your navel." In the forward bending and sitting posture the eyes go to the navel naturally, and the mind is entirely centered on the navel. This is one location where "dhāranāa" of yoga can take place as mentioned in the commentary of the Yoga Sūtras.

It is well known that the hesychasts were made fun of by their opponents with a derogatory name, omphalopsychoi, "people having a soul in a navel." Therefore an advocate of hesychasm, Gregorios Palamas (1296-1359), explained in response to this criticism that the mental concentration on a seemingly strange part of the body could be equivalent to nothing but the concentration on the "heart." Therefore he uses the expression "the navel" in vindication of Ps.-Symeon, while supplementing the word "concentration to chest" to avoid misunderstanding. ${ }^{38}$ Anyhow, it is should be noted that the method of the Jesus Prayer contains a teaching similar to that of dhārañā as a method of the concentration of mind.

In addition, the Yoga Sütras tell us that as one continues dhārañā where the presented ideas are consistently associated with the objects of concentration until no foreign 
thoughts intrude, one proceeds to the next stage of yoga, the seventh limb, dhyāna (meditative contemplation). ${ }^{39}$

\subsection{Continuous repetition of an invocation}

According to the hesychast method of Ps.Symeon, "as soon as the intellect attains the place of the heart," i.e. the state of entire stillness of the intellect, one should begin "the invocation of Jesus Christ." Nikephoros specifies the invocation as the words "Lord Jesus Christ, Son of God, have mercy on me," and he emphasizes that one "should never stop doing this."

Both Nikephoros and Ps.-Symeon assert that breath control has a preparatory role for the Jesus Prayer. On the other hand, we find the following passage in Centurie, another hesychast text written after the two texts mentioned in section 3.2: "With a breath going through the nose put it (i.e. the nous) in your heart calmly and say 'Lord Jesus Christ, Son of God, have mercy on me', while attaching the words of the prayer to your breathing in one way or another." ${ }^{40}$ Hence the prayer may be done either before, after, or with each step of the breathing.

Yoga has a similar practice, "svādhyāya," meaning "self-study," in one form or another, and this may be in relation to the Vedic scriptures to know about God and the true Self or it can also refer to "japa" (repetitive chanting). In the Yoga Sütras this chanting is of the sacred word "Om," ${ }^{41}$ which is a representation of "iśvara" or the "special Purusa" to whom one devotes oneself to attain meditative absorption or samādhi. ${ }^{42}$ This special Purusa is unaffected by the obstacles pertaining to spiritual practice, specific actions and their consequences, or any memories or desires. ${ }^{43}$ In íśvara also the seed of all knowledge is unsurpassed, and he is the teacher of the "first ones" because of his temporal continuity. ${ }^{44}$ This î́vara is not cognate with the Christian personal God. He is an ideal form of Purusa and helps the yogi to arrive at the "state of perfect spiritual concentration," through the last limb called "samādhi." The Yoga Sütras thus contain a theistic element, bringing issvara into the context of yoga practice and suggesting surrender to iśvara as a means of attaining the highest state of meditative absorption. In its conceptualization it is remarkably different from other theistic systems, indicating a pure form of the root Consciousness of Puruṣa.

The Jesus Prayer itself has a role similar to the idea of svādhyāya (self-study) and î́vara pranidhāna (surrender to ísvara). The purpose of saying this prayer repeatedly is to drive away idle thoughts and images, or emotions that disturb the inner stillness in meditation. Ps.-Symeon says that "from then on, from whatever side a distracting thought may appear, before it has come to completion and assumed a form, the intellect immediately drives it away and destroys it with the invocation of Jesus Christ." In the document of Nikephoros, this prayer "protects the intellect from distraction, renders it impregnable to diabolic attacks." The state of inner stillness is not identified with a state of hypnosis or selfoblivion, but, on the contrary, it is a state of high awakening with clear discrimination. This requires a mental attitude of constant surveillance of the mind and defense against "logismoi" (thoughts) welling up from one's inner world and threatening the quietness of the heart. This internal condition has been 
traditionally called "nepsis" (waking, sober) and its internal dynamic "prosoche" (attention, watching). ${ }^{45}$ The Jesus Prayer is the practice that incorporates nepsis and prosoche, alertness and attention. In this sense it may be said that the practice of this prayer is considered to play a supporting role for acquisition of the "theoria" just as "iśvara praṇidhāna" supports the acquisition of "samādhi," meditative absorption.

\subsection{Mystical experience}

An ultimate mystical experience such as "union" or "fusion" with the Absolute is called in the hesychast tradition, "theoria" (contemplation). The theoretical explanation of this kind of experience was systematized by Euagrios Pontikos in the $4^{\text {th }}$ century and thereafter became established in Eastern monasticism. Euagrios defined this experience as the vision of God through the vision of the state of the intellect itself in its own light at the time of the prayer. ${ }^{46}$ It is the vision of God that the intellect (nous) experiences through the vision of its own state, more precisely through the vision of its own light at the time of the prayer. The nous sees itself as "light-shaped" (phōtoeidēs). Euagrios marks this state as "a light appropriate to the nous," and says, "the nous begins to see its own light (oikeion pheggos)." However this light is no creation of the nous itself but a reflection of the light of the Trinity. The nous "receives" it like the light of a "lamp;" it receives "the light of the Holy Trinity at the time of the prayer." The nous itself is a mirror, "in which it is able to see God as it were indirectly," "indirectly" in the sense that God can never be seen in this World "face to face," but according to Euagrios, as a reflection in the still and silent intellect.
The true contemplation of the Trinity arises through the knowledge of the soul of itself. ${ }^{47}$ The basis for this opinion is an old principle, according to which recognizing means "for the subject to become same with the object." ${ }^{48}$ According to Euagrios, the Trinity is "substantial knowledge" (gnōsis ousiōdēs) ${ }^{49}$ in itself. In accordance with this principle, the nous, the organ of the theoria, must become the "same" with the Trinity, i.e. be blessed with His "substantial knowledge," making the nous complete in itself. This basic principle of becoming the same applies to the vision of God, because the nous possesses its "image of God" as the kernel of the created person or, more exactly, "the complete image of the Trinity." 50 This perfection of the nous is subsequently nothing but the perfection of the image of God in the nous as Euagrios explains: "If the nous becomes worthy of the contemplation of the Holy Trinity, it is then called God by mercy as it is accomplished in the creator's image himself." 51 The human being is thus godlike on the basis that he "is in a position to reach the Holy Trinity." 52

The psycho-physical method of the Jesus Prayer aims also at theoria, and this, according to the hesychast texts, can be accompanied by certain psychological phenomena. The accompanying phenomena mentioned by Ps.Symeon and Nikephoros are "sense of joy" and "experience of light." As for the former, Ps.Symeon points out that the nous, when it finds "the place of heart," it will find, as though miraculously, "an unceasing joy." Nikephoros, too, says that the nous "is filled with indescribable delight." In the history of the monastic tradition in Eastern Christianity we find lots of references to joy felt in the mysterious experience of God. ${ }^{53}$ In terms of the 
experience of light, Ps.-Symeon says that "as soon as the intellect attains the place of the heart, it beholds itself entirely luminous." This is the experience of light as explained by Euagrios. ${ }^{54}$

On the other hand, we don't find any description of the experience of light in Nikephoros. Instead he says to the readers of his document on his psycho-physical method, "All of you have a burning desire to get the manifestation of strong and divine light (phôtophaneia) of our Savior Jesus Christ," 55 thus implying that the experience of "the manifestation of the light of Christ" is that which is desired. This is the idea of the "Tabor Light" peculiar to hesychasm, and the light may be taken as "the light that is emitted by the body of Christ in transfiguration." ${ }^{56}$

The ultimate mystical experience of yoga is said to arise in the practice of the eighth limb, samādhi or meditative absorption, which is the state of kaivalya or the aloneness of the Puruṣa. The Yoga Sūtras says that in samprajñāta samādhi only the object shines forth, being empty of its essence." ${ }^{57}$ This means that the distinction between the subject and object is extinguished entirely, and in such a state of clear undifferentiated mind, only the object (arthamātra) "shines forth" (nirbhāsa). The final stages of Patañjali's aștānnga-yoga are the graded samādhi-s, which is either "with seed," (sabīja samādhi) i.e. has an object for contemplation and absorption, or it is "without seed" where there is no object involved (nirbija samādhi). The saminrajñāta-samādhi can be said to be the former type and the asamprajñātasamādhi corresponds to the latter, which then leads the practitioner of yoga to the ultimate goal of yoga, the kaivalya of Purușa. Thus in the final state of non-cognitive or nirbīja samādhi, there is no object, and the clear mind reflects the light of the self-luminous Purusa. This "union" of the clear mind with the light of the Purusa is similar to the mystical experience of the hesychast light.

In theistic mysticism as in Christianity, the object of the union is God himself, but in yoga it is not God but the "light" of Purușa, and the method is the ceasing of the modifications of the mind through yoga practices. It is when this state of stillness of the mind is arrived at there is the "aloneness" of the Purușa. In hesychasm, the nous itself as subject of the theoria becomes the object to be contemplated. In the final samādhi the subject is extinguished and there is a total identity between the pure mind and the self-luminous Purușa, whereas in hesychasm the subject, far from becoming extinguished, experiences its supreme form with the nous in the heart, shining with the light of God.

The samprajñāta-samādhi still has an object of contemplation, and according to the object of meditation, Patanjali describes four types of samādhi with an object: ${ }^{58}$

1) vitarka (Contemplation: meditation on gross objects such as physical objects and phenomena),

2) vicāra (reflection: meditation on subtle objects such as mental phenomena),

3) ānanda (joy: meditation on the inner joy) and

4) asmitā (I-am-ness: meditation on the sense of I-am).

As these are practiced, the level of absorption increases to more and more subtle states of consciousness where samprajñātasamādhi deepens. Here the notion of ānanda, or joy, is significant, as there is an experience of 
joy in both traditions related to the practices, but it is to be noted that this arises in different contexts and stages of practice. For the yogin, a state in which the modifications of the mind have been restricted to the object of meditation, there is greater stillness and calmness of the mind. In this state the joy that is experienced is held by the yogin in the consciousness to the exclusion of everything else.

The joy experienced by the hesychast as the nous finds its place in the heart. At this stage the hesychast has arrived at the ultimate internal quietness, because the nous is no longer wandering about. In this state of calmness the experience of "light" is the source of joy and it is the ultimate state of communion. Although the experience of joy may be similar, there is, however, a difference in terms explaining the source of this joy. For the yogin, the joy arises as a result of the restriction of the modifications of the mind that bring about the inner stillness. For the hesychast, the sense of joy is an epiphenomenon, an ultimate state of the mystical experience of the light. The yogin, on the other hand, has not yet reached the final goal of kaivalya.

In the stage of the samprajñāta-samādhi there remain "cogitation, reflection, joy or Iam-ness (asmitā). ${ }^{59}$ When these 'objects' of absorption have passed away step by step, the yogin enters the final stage of asamprajñātasamādhi. This samādhi is a stage beyond cognition retaining only "unmanifested impressions" (samskāra). ${ }^{60}$ When these have been rendered without any potency to manifest through intense practice, there is nothing further for the yogin to practice, and the state of kaivalya is established. The Puruṣa has now separated from the entanglement with the Prakrti, through the involution of the elements of Prakrti. Here then the final goal of yoga is achieved where the "Seer" or Purușa gets established in its own nature. ${ }^{61}$

\section{Conclusion}

With a comparative analysis between the method of aștānnga-yoga in the Yoga Sūtras and the psycho-physical method of hesychasm, the following conclusions can be arrived at:

1) Both speak of the need of daily ascetic practices for the purpose of purification before entering the concrete practices. Hesychasm calls these the praxis, and in the Yoga Sütras they are the first two limbs of yama and niyama.

2) Both have a sitting style as a basic bodily posture, and in both traditions this posture is required as the basis for the other concrete practices. But in the case of the Jesus Prayer a certain forward-bending posture is required which leads to a painful experience of the body, whereas in the àsana of the Yoga sütras the recommended bodily posture leads to stability and pleasantness and are suitable for long periods of meditation.

3) Both advise a form of breath control. For the hesychast, breathing in combination with the Jesus Prayer is recommended in order to realize a thorough internal quietness expressed in the symbolism of the "introduction of the nous into the heart." The Yoga Sütras emphasize the practice of prāñāyāma as a way for realizing internal quietness expressed in the term "no disturbances from the dualities," a state of indifference to the dualities such a heat and cold. 
4) Both have practices for training of attention to concentrate on certain objects for contemplation and meditation as a method of bringing about inner calmness and quietness. But a certain difference is to be seen in the emphasis placed on this practice by the two traditions. As far as the Jesus Prayer is concerned, Ps.-Symeon chooses the navel as the object and Gregorios Palamas, the chest, but Nikephoros doesn't mention these at all. On the contrary, in the Yoga Sütras in the practice of dhāranāa, there is relative freedom in the choice of objects for the initial stages but this becomes restricted as the practice progresses towards the other limbs of yoga. In the samprajñāta-samādhi there are four "objects," whereas in the final stage of asamprajñāta-samādhi there is no object involved in meditative absorption.

5) Both recommend continuous repetition of an invocation. The invocation in hesychasm is the Jesus Prayer and in the svādhyāya of the Yoga Sūtras it is the sacred syllable "Om" or readings from the sacred books. Although these appear similar in terms of the method, in hesychasm the repetition of Jesus Prayer has a central role in the psycho-physical technique, whereas the svādhyāya and iśvara praṇidhāna are mentioned as preparatory stages of aștāninga-yoga. Herein we also see a difference between the Christian faith with a personified God and the yoga characterized by its non-personified image of iśvara, a special form of Puruṣa or pure consciousness. Another important point of difference is that in hesychasm human effort and ability are certainly required for the achievement of purpose, but theoria can be attained exclusively by the grace of God. In the case of yoga, however, although one relies on the help of God, the achievement of the final stage, kaivalya is a result of human effort and ability. The Yoga Sūtras speak of īśvara pranidhāna, the notion of devotion to iśvara, which is said to bring about the restriction of the modifications of the mind.

6) Both refer to a process of turning into one's inner world for the achievement of the goal. The hesychasm aims for the theoria, i.e. the vision of God through the vision of the state of the nous coming in its own light by its introduction into the heart. One meets God, the absolute Other beyond the universe, in the place of beatitude filled with the Divine Light in one's very inner world. The ultimate goal of yoga is that one transcends the material nature which has arisen out of ignorance and becomes established in the Purușa which in a sense, is hidden in the depth of one's consciousness. In addition, the experience of joy is observed in both traditions, but this appears, in the case of yoga, only on the way towards the ultimate stage of nirbija-samādhi and is an experience which arises from the restriction of the modifications of the mind.

7) Both speak of reaching a self that is beyond the ordinary experience of oneself. According to the Eastern monastic tradition following Euagrios, the theoria means the highest state of the nous as the "image of God." The theoria is the ultimate experience of God that a human being is able to attain, and it means that the nous finding its place in the heart reaches its perfection in the image of God. On the other hand, in the Yoga Sütras the true self is the Puruṣa attained through the practice of yoga when there is a separation of the material and consciousness principles. However, the 
understanding of the nature of selfrealization appears to be very different. In hesychasm it is the nous, the core of self, which when stilled as it reaches its place in the heart, receives the light of God and itself shines as God, a fusion or union of the nous with the light of God. In the Yoga Sütras the ultimate realization is that of the Purusa, the true self, which has been extricated from its

\section{Notes}

${ }^{1}$ In the Russian Church the following phrase is generally accepted: 'Jesus Prayer', 'Lord Jesus Christ, Son of God, have mercy on me, a sinner'. Cf. Ilarion(Schimonach), Auf den Bergen des Kaukasus. Geschpräch zweier Einsiedler über das Jesus-Gebet, übers. u. Vorw. v. B. Tittel, Salzburg 1991.

${ }^{2}$ E. von Ivánka, "Byzantinische Yogis?," Zeitschriften der Deutschen Morgenländischen Gesellschaft 102 (1952): 234-239.

${ }^{3}$ As English translation of texts of the Yoga Sūtras we use: Gerald James Larson and Ram Shankar Bhattacharya (ed.) Yoga: India's Philosophy of Meditation. Vol. XII of the Encyclopedia of Indian Philosophies (Delhi: Motilal Banarsidass, 2008), 162-183. See also: Hariharananda Aranya, Yoga Philosophy of Patanjali (New York: SUNY Press, USA, 1983).

${ }^{4}$ Yoga Sūtras I.2: yogas-citta-vr̦tti-nirodha.

${ }^{5}$ Yoga Sūtras I.6: pramāna, viparayaya vikalpa nidrā smrtiyah.

${ }^{6}$ Ved Vyāsa, Yoga Bhāşya I. 8.

${ }^{7}$ I. Whicher, Yoga Darsana, A Reconsideration of Classical Yoga (Delhi: D K Printworld, 2000), 119.

${ }^{8}$ G Feuerstein, The Philosophy of Classical Yoga (Rochester, VT: Inner Traditions/Bear \& Company, 1996), 64.

${ }^{9}$ I. Whicher, op.cit., 110. entanglement with Prakrti and is in a state of "aloneness."

The comparative analysis of the two traditions of hesychasm and yoga has yielded interesting points of superficial similarities in terms of physical and mental exercises and deeper differences related to the theological principles on which these traditions are based.

${ }^{10}$ See commentary of Vyāsa on sūtra II.24.

${ }^{11}$ Yoga Sūtras II.30.

${ }^{12}$ Yoga Sūtras II.32.

${ }^{13}$ Yoga Sūtras II.46.

${ }^{14}$ Yoga Sūtras II.47.

${ }^{15}$ Yoga Sūtras II.49 - 53.

${ }^{16}$ Yoga Sūtras III.1.

17 G Flood, An Introduction to Hinduism (Cambridge: Cambridge University Press, 1996), 233-234.

${ }^{18}$ Yoga Sūtras IV.34.

${ }^{19}$ Greek text in PG 147:945-66; also in Ph. [= Philokalia ton Ieron Niptikon (Athens 1957-63), vol. iv], 18-28. English Translation in E.

Kadloubovsky and G. E. H. Palmer, Writings from the Philokalia on Prayer of the Heart (London:

Faber and Faber, 1951), 22-34.

${ }^{20}$ Nikephoros came originally from Italy, and was apparently a Latin brought up in the Western rite, not a Greek from Calabria. Becoming convinced that the West had fallen into "kakodoxy," he travelled to the Byzantine Empire and joined the Orthodox Church. He became a monk on the Holy Mountain of Athos, living there in "quietness and stillness." according to Palamas, and eventually withdrew to the "most isolated regions" on the Mountain. Nikephoros himself has left a description of the persecution that he underwent because of his opposition to the unionist policy of Emperor 
Michael VIII. He was arrested in 1276, taken to Constantinople and then to Acre, where he was tried before a Latin judge and exiled to Cyprus, although he was released in the following year. He probably died before 1300 .

${ }^{21}$ Greek text in Irénée Hausherr, La méthode d'oraison hésychaste (Rome: Pont. Institutum Orientalium Studiorum, 1927), 150-172.

${ }^{22}$ Peri nepsôs = Phi IV, 27,4-30. However the first sentence is an interpolation by Hausherr. I.

Hausherr, La méthode, op. cit., 130.

${ }^{23}$ Methodos = I. Hausherr, La méthode, op. cit., 164,6-165, 15.

24 "Apatehia is flowering of praxis" (Euagrios, Practicus 81= A. Guillaumont / C. Guillaumont (ed.), Évagre le Pontique. Traité Pratique ou Le Moine, t. II (SC 171), Paris 1971, 670.

${ }^{25}$ Gregorius Sin., Peri hesychias 2 = Phi IV, 71,31.

${ }^{26} \mathrm{Ibid} .=$ Phi IV, 71,32.

${ }^{27} \mathrm{Cf}$. Gregorius, Peri tou pôs kai kathezesthai $=\mathrm{Phi}$ IV, 80, 15.

${ }^{28} \mathrm{Ibid}$. = Phi IV, 80, 7-8.

${ }^{29}$ Cf. Irénée Hausherr, Penthos. La doctrine de la componction dans l' Orient chrétien, Rome: Pont. Institutum Orientalium Studiorum, 1944.

30 M Bakic-Hayden, "Two methods of contemplation, Yoga and Hesychast prayer," Bulletin of the Institute of Ethnography SASA LVI (2), 2008: 174.

${ }^{31}$ Cf. Methodos = I. Hausherr, La méthode, op. cit., 159,16-160,2; Peri nepseôs = Phi IV, 27,17-19.

${ }^{32}$ Yoga Sūtras II.49 - 50.

${ }^{33}$ Yoga Sūtras II.51 - 53.

${ }^{34}$ M. Eliade, Yoga: Immortality and Freedom (Princeton: Princeton University Press, 2009), 65: "We must not be deceived by these external analogies with prānāyama. Amongst the Hesychasts (these) are used to prepare mental prayer; in the Yoga-sūtras these exercises pursue unification with consciousness and preparation for meditation, and the role of God (Iśvara) is comparatively small."

${ }^{35}$ Yoga Sūtras II.48: tato dvandvānabhighāta.

${ }^{36}$ Yoga Sūtras II.54-55.

${ }^{37}$ Yoga Bhāṣya, Sādhana-Pāda sūtra 55.

${ }^{38}$ Gregorius Palam., Triades 1,2,8 = J.

Meyendorff, Grégoire Palamas. Défense des saints hésychastes (SSL 30), Louvain 1959, 91,1-18.

${ }^{39}$ Cf. Yoga Sūtras I.51.

${ }^{40}$ Centurie 25 = Phi IV, 224, 25-28.

${ }^{41}$ Cf. Yoga Sūtras I.28: taj-japas-tad-arthabhāvanam: "The recitation of that (OM) leads to the contemplation of its meaning."

${ }^{42}$ Cf. Yoga Sütras I.23: ìsvara-pranidhāna-vā: "Or (samādhi is gained) through devotion to îsvara'.

${ }^{43}$ Yoga Sūtras I.24.

${ }^{44}$ Yoga Sūtras I.25-26.

${ }^{45}$ Cf. P. Adnès, 'Nepsis', Dictionnaire de

Spiritualité, vol. 11 (1982), 110-118.

${ }^{46}$ Cf. A. Guillaumont, "La vision de l'intellect par lui-même dans la mystique évagrienne," Mélanges de l'université Saint Joseph 50 (1984), 255-262.

${ }^{47}$ Cf. Epistula 29 = ed. W. Frankenberg, op. cit., 587.

${ }^{48} \mathrm{~J}$. Lemaitre / R. Roques / M. Viller, art. Contemplation III, I. Étude de vocabulaire, DSp 2 (1953), 1779.

${ }^{49}$ Kephalaia gnostica 2,47 = ed. A.Guillaumont, Les six Centuries, op. cit., 78.

${ }^{50}$ Ibid., 3,28 = 108 .

${ }^{51}$ Ibid. $5,82=210$.

${ }^{52}$ Ibid. $6.73=246$.

${ }^{53} \mathrm{~K}$. Ware, "The Jesus Prayer in St. Gregory of Sinai," ECR 4 (1972):20.

${ }^{54}$ Euagrios, Prakticus 64 = A. Guillaumont $/ \mathrm{C}$. Guillaumont, op. cit., 648; Capita Cognoscitiva $3=$ 
J. Muyldermans, Evagriana (Muséon 44), Louvain 1931, 51.

${ }^{55}$ Peri nepseôs = Phi IV, 18, 6-7.

${ }^{56}$ D. Balfour (ed.), "Saint Gregory the Sinaite. Discourse on the Transfiguration. First critical Edition, with English and Commentary",

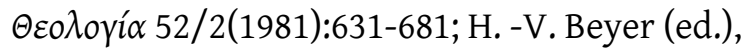
"Die Katechese des Theoleptos von Philadelpheia auf die Verklärung Christi," JÖB 34 (1984):188-194.

${ }^{57}$ Yoga Sūtras III.3: tadaeva artha mātra nirbhāsam svarūpa śūnyam iva samādhih.

${ }^{58}$ Yoga Sūtras I.17: vitarka vicāra ānanda asmitā anugamāt samprajñāth.

${ }^{59}$ Ibid., Yoga Sūtras I.17.

${ }^{60}$ Yoga Sūtras 1.18.

${ }^{61}$ Yoga Sūtras I.3: tadā draștuh svarūpe avasthānam.

\section{REFERENCES:}

M. Bakic-Hayden, "Two methods of contemplation, Yoga and Hesychast prayer," Bulletin of the Institute of Ethnography, SASA LVI (2), 2008:171-181.

D. Balfour (ed.), "Saint Gregory the Sinaite. Discourse on the Transfiguration. First critical Edition, with English and

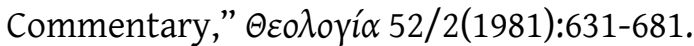

$\mathrm{H}$-V. Beyer (ed.), “Die Katechese des Theoleptos von Philadelpheia auf die Verklärung Christi,“JÖB 34 (1984):171-198.

M. Eliade, Yoga: Immortality and Freedom, UK: Princeton University Press, 2009.

G. Feuerstein, The Philosophy of Classical Yoga, Rochester, VT: Inner Traditions/Bear \& Company 1996.

G. Flood, An Introduction to Hinduism, Cambridge: Cambridge University Press, 1996.
A. Guillaumont, "La vision de l'intellect par luimême dans la mystique évagrienne," Mélanges de l'université Saint Joseph 50 (1984):255-262.

A. Guillaumont et C. Guillaumont (ed.), Évagre le Pontique. Traité Pratique ou Le Moine, Two volumes, (SC 170-1), Paris, 1971.

I. Hausherr, La méthode d'oraison hésychaste, Rome: Pont. Institutum Orientalium Studiorum, 1927.

I. Hausherr, Penthos. La doctrine de la componction dans l' Orient chrétien, Rome: Pont. Institutum Orientalium Studiorum, 1944.

E. Hisamatsu, The Psychophysical Method of Prayer: Byzantine Hesychasm of the 14th Century, Kyoto: Kyoto University Press, 2009 (in Japanese 352 pp.).

Hariharananda Aranya, Yoga Philosophy of Patanjali, (Albany, NY: SUNY Press), 1983.

E. von Ivánka, "Byzantinische Yogis?," Zeitschriften der Deutschen Morgenländischen Gesellschaft 102 (1952):234-239.

E. Kadloubovsky and G. E. H. Palmer (translators), Writings from the Philokalia on Prayer of the Heart, London: Faber and Faber, 1951.

G. J. Larson and Ram Shankar Bhattacharya (ed.) Yoga: India's Philosophy of Meditation. Vol. XII of the Encyclopedia of Indian Philosophies. Delhi: Motilal Banarsidass, 2008.

J. Lemaitre, R. Roques, M. Viller, Contemplation III, I. Étude de vocabulaire, DSp 2, 1953.

J. Meyendorff (ed.), Grégoire Palamas, Défense des saints hésychastes, (SSL 30), Louvain: Peeters, 1959.

R. Pattni, A Psychological Understanding of the Yoga Sūtra of Patañjali, with a Comparative 
Analysis of Samādhi and Flow, unpublished doctoral thesis, University of Oxford, 2015.

K Ware, "The Jesus Prayer in St. Gregory of Sinai," ECR 4 (1972):3-22.

I. Whicher, Yoga Darsana, A Reconsideration of Classical Yoga, Delhi: D. K. Printworld, 2000.

D. G. White (ed.), Yoga in Practice, Princeton:

Princeton University Press, 2012. 